\title{
PENGARUH PELATIHAN KEPEMIMPINAN TRANFORMASIONAL SUPERVISOR TERHADAP MUTU PELAYANAN PRAMUNIAGA DI FLORA GROUP
}

\author{
Dian Yudhawati ${ }^{1}$, Alimatus Sahrah ${ }^{2}$, Reny Yuniasanti ${ }^{3}$ \\ ${ }^{123}$ Fakultas Psikologi Universitas Mercu Buana Yogyakarta \\ 123dianwaskito2012@yahoo.co.id
}

\begin{abstract}
Abstrak
Tujuan dari penelitian ini adalah untuk mengetahui efektivitas pelatihan kepemimpinan transformasional supervisor terhadap mutu pelayanan pramuniaga. Mutu pelayanan pramuniaga termasuk penampilan fisik, responsif, tanggung jawab, jaminan dan empati. Sedangkan kepemimpinan transformasional terdiri dari 5 aspek, idealized influenced, inspirational motivation, intellectual stimulation dan individualized consideration. Terdapat tiga puluh dua karyawan Flora Grup yang terlibat dalam penelitian ini menggunakan kuasi eksperimental design yang mengukur pretest dan post test kelompok kontrol dan kelompok eksperimen. Hasil analisa data post test, $t=10,775$, dengan $p=0,000$ yang artinya ada perbedaan yang signifikan antara kelompok eksperimen dan kelompok kontrol.
\end{abstract}

Kata kunci : pelatihan kepemimpinan transformasional, mutu pelayanan pramuniaga.

\section{THE IMPACT OF SUPERVISOR TRANSFORMATIONAL LEADERSHIP TRAINING TOWARD SALES PERSON'S SERVICE QUALITY AT FLORA GROUP}

\author{
Dian Yudhawati ${ }^{1}$, Alimatus Sahrah ${ }^{2}$, Reny Yuniasanti ${ }^{3}$ \\ ${ }^{123}$ Psychology Faculty of Mercu Buana University of Yogyakarta \\ 123dianwaskito2012@yahoo.co.id
}

\begin{abstract}
The purpose of this research is to recognize the effective of transformational leadership training, on salespersons' service quality. The service quality include tangible, responsibility, responsiveness, assurance and emphaty. Meanwhile transformational leadership include four aspect, they are idealized influenced, inspirational motivation, intellectual stimulation and individualized consideration. There are thirty two Flora Group's employees who were involved in this study. This research uses quasi experimental design that measures pre test post test control group design using the experimental group and the control group. The analysis result on post test data is, $t=10,775$, with $p=0,000$ which means, there is significance differences between control group and experimental group.
\end{abstract}

Keywords : transformational leadership training, salespersons' service quality 


\section{PENDAHULUAN}

Pada era globalisasi sekarang ini banyak industri dan organisasi mengalami perubahan. Termasuk dengan perubahan-perubahan dalam dunia usaha yang terjadi secara dinamis sehingga mengharuskan tiap-tiap perusahaan bergerak pula mengikuti perkembangan yang ada dengan mengoptimalkan segala bentuk lininya. Hal ini terjadi karena adanya perkembangan usaha manufaktur dan peluang pasar yang cukup terbuka karena lajunya kondisi sosial ekonomi masyarakat serta adanya perubahan sistem nilai yang terjadi (Johannes, 1986).

Perkembangan ini terjadi pula di Daerah 1stimewa Yogyakarta, dimana masyarakat tertarik untuk memenuhi kebutuhan dan gaya hidup di berbagai pertokoan yang kini banyak dibangun. Menurut penelitian yang dilakukan oleh Fitri di Yogyakarta pada tahun 1999, diperoleh hasil bahwa pelayanan termasuk salah satu faktor penting dalam mempengaruhi sikap konsumen untuk berbelanja di suatu toko.

Hasil penelitian lainnya yang dilakukan Kusumo (1999) juga diperoleh kesimpulan bahwa pelayanan yang dilakukan dengan baik merupakan salah satu alasan konsumen untuk berbelanja di Matahari Galeria Yogyakarta. Dalam penelitian lain yang dilakukan oleh Matahari Department Store (1997) diketahui bahwa penyebab pelanggan lari adalah 3\% karena pindah tempat tinggal, $5 \%$ karena menemukan persahabatan baru di perusahaan atau toko lain, $9 \%$ karena bujukan pesaing, 14 $\%$ karena merasa tidak puas dengan produk yang dibelinya, $1 \%$ karena meninggal dan 68 $\%$ persen karena sikap masa bodoh dalam melayani.

Dalam penelitian itu ditemukan pula bahwa dengan pelayanan yang baik akan memperoleh rata-rata $12 \%$ tambahan pelanggan baru dan meraih pangsa pasar sebesar $6 \%$ pertahun dan biasanya mampu menetapkan harga yang cukup tinggi. Artinya harga bukan masalah bagi pelanggan apabila mutu pelayanan yang diberikan baik. Sebaliknya jika mutu pelayanan rendah maka perusahaan rata-rata hanya memperoleh tambahan $1 \%$ pelanggan baru dan kehilangan pangsa pasar sebesar $2 \%$ pertahun.

Setiap perusahaan bisnis eceran atau ritel berupaya untuk memberikan pelayanan yang memuaskan sehingga para pelanggannya mendapatkan suasana belanja yang menyenangkan. Pelayanan terbaik perlu dilakukan oleh seluruh karyawan yang ada. Kemampuan memberikan pelayanan yang bermutu tersebut dirasa perlu pula dilakukan oleh Flora Group yang juga bergerak di bisnis eceran atau ritel.

Menurut Parasuraman (1988), pelayanan tersebut antara lain adalah kemampuan dalam hal tampilan fisik (tangibles), kemampuan untuk memberikan pelayanan yang dapat diandalkan dan akurat (reliability), kemauan untuk membantu para pelanggan dan memberikan pelayanan dengan sebaik mungkin (responsiveness), pengetahuan dan kebaikan karyawan untuk memberikan kepercayaan dan keyakinan (assurance) serta kepedulian dan perhatian terhadap 
pelangganya secara individu (empathy).

Kenyataan yang terjadi berdasarkan hasil wawancara dengan Manager Flora Group pada tanggal 10 Juni 2015 menunjukkan bahwa pelayanan yang kurang bermutu menyebabkan tidak tercapainya target penjualan yang telah ditentukan. Target penjualan yang dimaksud adalah untuk toko flora sebesar 350 juta/bulan, toko fedsa 250 juta/bulan, toko Arrosi 200 juta/bulan, toko Top 200 juta/bulan, flora muslim modiste 250 juta/bulan dan flora distribusi sebesar 2, 5 M/bulan.

Pelayanan yang dimaksudkan di sini adalah pelayanan yang dilakukan oleh para pramuniaga. Pramuniaga merupakan asset sumber daya manusia yang memiliki peran besar dalam menunjang keberhasilan dan kemajuan perusahaan. Sebuah perusahaan baik itu sebagai penghasil barang ataupun jasa murni, memerlukan pramuniaga yang bertugas sebagai penghubung antara perusahaan dengan konsumen dalam menawarkan barang dan memberikan informasi mengenai kebutuhan konsumen pada perusahaan. Dengan demikian posisi pramuniaga tidak kalah penting dengan posisi lain dalam perusahaan.

Klasifikasi Jabatan Indonesia (1981) menyatakan bahwa pramuniaga meliputi tenaga penjualan dan pembantu di toko seperti tenaga kerja yang mengurus persediaan barang dan membantu pembeli di toko serba ada atau supermarket, memilihkan barang untuk layanan menurut permintaan tertulis maupun lewat telpon, memberi petunjuk dan membantu pembeli barang di supermarket.
Beberapa contoh pelayanan yang diketahui pada saat observasi pada tanggal 30 Mei dan 4 Juli 2015 di toko-toko Flora Group antara lain adalah penampilan pramuniaga yang kurang rapi, tidak mematuhi aturan berseragam yang telah ditentukan perusahaan, tidak dapat menjelaskan fungsi barang yang dijualnya, jawaban antara satu pramuniga dengan pramuniaga lainnya berbeda pada suatu produk yang sama, jika ditanya pada waktu yang berbeda, jawabannya berbeda pula, pramuniaga tidak cepat tanggap dengan kehadiran dan kebutuhan konsumen, pramuniaga sering duduk bergerombol dengan kawannya pada saat jam kerja, pramuniaga tidak dapat meyakinkan konsumen tentang fungsi barang yang dijualnya agar sesuai dengan kondisi konsumen, pramuniaga seringkali tidak melihat kondisi konsumen secara individu, inginnya barang yang dijualnya segera laku terjual saja.

Hal tersebut tidak dapat dibiarkan terus menerus karena mutu pelayanan merupakan hal penting bagi keberlangsungan hidup suatu perusahaan. Menurut Pranowo (2003) mutu pelayanan yang baik akan menciptakan kepuasan pelanggan yang dapat memberikan beberapa manfaat, di antaranya hubungan antara perusahaan dan pelanggannya menjadi harmonis, memberikan dasar yang baik bagi pembelian ulang, mendorong terciptanya loyalitas pelanggan, membentuk suatu rekomendasi dari mulut ke mulut (word of mouth) yang menguntungkan bagi perusahaan, reputasi perusahaan menjadi semakin baik dimana pelanggan serta laba yang diperoleh akan meningkat. 
Hasil penelitian Jefri dan Wijaya (2008) menunjukkan bahwa mutu pelayanan yang baik akan berpengaruh terhadap kepuasan, kepercayaan dan komitmen konsumen. Menurut Armstorng (2008) paradigma baru berpandangan bahwa produk atau jasa yang dihasilkan tidak perlu mengeluarkan biaya tinggi, tetapi dapat menghasilkan produk yang bermutu dan pelayanan yang memuaskan sehingga dapat dikatakan perusahaan tersebut sudah berorientasi pada customer satisfaction. Artinya produk atau jasa yang dihasilkan sesuai dengan kebutuhan dan harapan pelanggan. Dengan demikian tidak ada pemborosan yang terjadi yang harus dibayar mahal oleh perusahaan.

Tersedianya mutu yang baik dapat menyebabkan peningkatan pasar. Hal ini yang kemudian mendorong konsumen untuk membeli dan membeli lagi produk tersebut sehingga pangsa pasar meningkat. Artinya dengan mutu yang tetap terjaga, maka perusahaan akan tampak semakin bertanggung jawab terhadap proses dan hasil produksi maupun pelayanan tersebut untuk memenuhi kebutuhan pasar. Pelanggan akan menaruh rasa percaya dan selalu melakukan pembelian berulang di perusahaan tersebut.

Dalam penelitian ini yang dimaksud dengan mutu pelayanan pramuniaga adalah kemampuan dan kemauan pramuniaga untuk melayani pelanggan sesuai teori dari Parasuraman, Zeithaml dan Berry (1988) tentang dimensi pelayanan yang bermutu yaitu adanya penampilan fisik, reliabilitas, responsif, keyakinan serta empati. Adanya pramuniaga yang memiliki mutu pelayanan yang baik berarti perusahaan memiliki sumber daya manusia yang mampu menopang keunggulan kompetitif perusahan.

Sasaran pelayanan tidak sekedar meniadakan keluhan (complaint) atau memuaskan pelanggan, melainkan lebih dari itu (beyond customer satisfaction) sehingga upaya perusahaan untuk memuaskannya tidak semudah seperti yang diperkirakan. Untuk mencapai sasaran yang dimaksud, perlu komitmen dari jajaran pimpinan yang kuat untuk membangun budaya pelayanan (service culture) dalam organisasinya dengan pendekatan yang lebih dari pada sekedar pelatihan bagi customer service .

Rachman (dalam Aristika, 2001) menyatakan sukarnya mencari profesional marketing yang handal adalah problem umum dalam pengembangan sumber daya manusia di Indonesia. Kemampuan memberikan mutu pelayanan yang baik dalam situasi dan kondisi konsumen yang berbeda-beda dirasa masih kurang.

Kesulitan tersebut juga dinyatakan oleh pihak manajemen Flora Group. Mereka merasa perlu untuk memberikan mutu pelayanan yang baik karena mulai banyak berdiri toko-toko yang memiliki bisnis sejenis di kota Yogyakarta.

Purwanto dan Adisubroto (2001) menyatakan salah satu faktor yang ikut menentukan tinggi rendahnya mutu pelayanan adalah kepemimpinan di suatu organisasi. Morgan (dalam Kotler, 1997) menyatakan bahwa dalam memberikan pelayanan membutuhkan pembinaan karyawan secara 
menyeluruh, mulai dari pimpinan sampai dengan karyawan yang berhadapan langsung dengan pelanggan. Kepemimpinan merupakan masalah yang sudah tua dan berbagai macam teori telah dikembangkan untuk menerangkan proses-proses kepemimpinan. Salah satu teori kepemimpinan yang relatif baru dan menarik dicermati adalah kepemimpinan transformasional.

Jabnoun dan al Rasasi (2005) menyebutkan dalam penelitiannya bahwa kepemimpinan transformasional akan membawa mutu pelayanan yang baik dalam organisasi. Senada dengan penelitian tersebut, Peter dkk (2011) menambahkan bahwa dimensi dalam kepemimpinan transformasional memberikan pengaruh yang signifikan terhadap mutu pelayanan. Dimensi dalam kepemimpinan transformasional akan membawa bawahannya dalam suasana kerja yang menuntun kepada pembaharuan dan pengembangan diri karyawan kearah yang lebih baik dalam rangka pencapaian tujuan organisasi. Pengembangan diri tersebut salah satunya adalah dalam memberikan layanan yang lebih bermutu.

Suharta (2014) menyatakan dari hasil penelitiannya bahwa kepemimpinan transformasional memberi sumbangan efektif pada mutu pelayanan kesehatan sebesar 8,8\%. Temuan lain tentang besarnya sumbangan efektif kepemimpinan transformasional terhadap mutu pelayanan juga diperoleh dari hasil penelitian Yudhawati (2005). Dalam penelitiannya diperoleh hasil bahwa kepemimpinan transformasional yang dilakukan para supervisor memberikan sumbangan efektif sebesar 39, 845\% terhadap mutu pelayanan pramuniaga.

Gaya kepemimpinan transformasional memang saat ini yang cukup sering menjadi bahan penelitian karena dari Burns (1978) dan Bass (1990) dengan cukup meyakinkan mampu menjabarkan unsur-unsur kepemimpinan ini menjadi definisi operasional yang dapat diukur dan dibentuk (Riyono, 1998).

Berdasarkan berbagai kenyataan tersebut di atas maka penulis berminat untuk melakukan penelitian tentang pelatihan kepemimpinan transformasional supervisor untuk meningkatkan mutu pelayanan pramuniaga. Penelitian ini akan dilakukan di Flora Group karena pihak manajemen Flora Group merasa perlu memperhatikan mutu pelayanan melalui peran para pemimpin atau supervisornya. Para supervisor sebagai first line manager dianggap bertanggung jawab dalam memotivasi pramuniaga untuk memberikan pelayanan yang terbaik pada pelanggan sehingga mencapai target penjualan yang telah ditentukan.

Berdasarkan kerangka teoritis serta didukung oleh hasil penelititian sebelumnya, maka dapat diajukan hipotesis penelitian sebagai berikut : Mutu pelayanan pramuniaga yang supervisornya diberi pelatihan kepemimpinan transformasional lebih tinggi daripada mutu pelayanan pramuniaga yang para supervisornya tidak diberi pelatihan kepemimpinan transformasional.

\section{METODE}


Metodologi pelatihan ini dikembangkan berdasarkan tata cara belajar dari pengalaman (experiential learning), belajar sebagai kelompok (team learning), dan peningkatan efektifitas tindakan (action learning). Bahan utama pembelajaran adalah pola perilaku kerja sama, baik yang ditampilkan oleh dirinya sendiri, maupun oleh sesama peserta pelatihan. Experiential learning itu adalah proses belajar, proses perubahan yang menggunakan pengalaman sebagai media belajar atau pembelajaran. Experiential learning adalah pembelajaran yang dilakukan melalui refleksi dan juga melalui suatu proses pembuatan makna dari pengalaman langsung. Experiential learning berfokus pada proses pembelajaran untuk masing-masing individu (Kolb 1984). Experiential learning adalah suatu pendekatan yang dipusatkan pada peserta pelatihan yang dimulai dengan landasan pemikiran bahwa orang-orang belajar terbaik itu dari pengalaman. Pengalaman belajar yang akan benar-benar efektif, harus menggunakan seluruh roda belajar, dari pengaturan tujuan, melakukan observasi dan eksperimen, memeriksa ulang, dan perencanaan tindakan. Apabila proses ini telah dilalui memungkinkan peserta pelatihan untuk belajar keterampilan baru, sikap baru atau bahkan cara berpikir baru.

Experiential learning memiliki lima tahapan, yaitu: experiencing, publishing, processing, generalizing, dan applying. Experiencing (activity “doing”) adalah tahap individu maupun kelompok melakukan aktivitas, diantaranya membuat suatu produk, menciptakan karya seni, melakukan transaksi, memecahkan masalah, menulis, memilih sesuatu, dan lain-lain. Individu atau kelompok tersebut melakukan pengumpulan data dan kemudian melakukan generalisasi data. Publishing (sharing reactions and observation) adalah orang yang telah melakukan aktivitas, pada tahap ini akan membagikan pengalamannya, apa yang mereka lihat dan rasakan selama melakukan kegiatan pada yang lain. Pada tahap ini dilakukan suatu pencarian tentang apa yang terjadi dala diri orang tersebut dengan bantuan anggota lain. Processing (discussion of patterns and dynamics). Ini merupakan tahap yang kritis dalam experiential learning, dimana dilakukan systematic examination of commonly shared experienced oleh orang yang bersangkutan. Orang akan melakukan perbaikan setelah pada tahap sebelumnya mereka menerima masukan-masukan. Generalizing (interning principles about the "real world"). Di tahap ini dilakukan pencarian general trends and truth dalam pengalaman yang telah mereka lakukan. Peserta melihat pengalaman mereka, dan menentukan bagaimana hal itu dapat digunakan. Orang dibimbing untuk memusatkan perhatiannya pada kesadaran bahwa keadaan pada kehidupan pribadi atau dalam pekerjaan mereka serupa dengan kegiatan yang mereka alami. Bahwa apa yang mereka alami dapat diterapkan juga pada kehidupan mereka. Applying (planning more effective behavior). Pada tahap akhir ini juga merupakan sasaran dari dilakukannya structured experience. Tugas trainer dalam hal ini adalah membantu peserta untuk 
menerapkan apa yang sudah digenaralisasi pada tahap sebelumnya kepada keadaan nyata. Dilakukan modifikasi tingkah laku yang lama atau mencoba suatu perilaku baru dan melatihnya dalam kehidupan sehari-hari.

Pelatihan

Kepemimpinan

Transformasional dimulai dengan sesi ice breaking, kemudian masuk pada sesi idealized influence. Pada sesi ini, peserta pelatihan diberi materi untuk (1)mengartikulasikan visi dan menjelaskan bagaimana untuk mencapai visi tersebut. (2) memimpin dengan contoh bertindak percaya diri dan optimis berbagi risiko. (3) menekankan nilai-nilai dan memperkuat karyawan dengan tindakan simbolis perilaku etika dan moral. Pemimpin yang menerapkan pengaruh ideal pada pengikut mereka mendapatkan kepercayaan dan keyakinan dari para pengikut. Para pengikut mengagumi pemimpin sebagai panutan dan menghormati keputusan yang diambil.

Dalam sesi inspirational leadership, para peserta diberi pelatihan yang bertujuan (1) mengartikulasi pandangan yang jelas dan menarik dari perkembangan masa depan visi bersama baik secara ekonomi dan ideologis sehingga karyawan mampu melihat makna dalam pekerjaan mereka. (2) memastikan peran masing-masing karyawan $\mathrm{dlm}$ pemenuhan visi. (3) menetapkan standar tinggi untuk para karyawan dalam mencapai tujuan. (4) mendorong karyawan untuk mengintegrasikan dan menjadi bagian dari organisasi dan lingkungan.

Untuk sesi intellectual stimulation, peserta diberi pelatihan agar mampu (1) mendorong perubahan melalui stimulasi intelektual yang bertujuan untuk perubahan diri mencerminkan nilai-nilai dan keyakinan. (2) meningkatkan kesadaran dan mengembangkan kemampuan karyawan untuk memecahkan masalah. (3) menciptakan lingkungan yang kondusif bagi penciptaan dan berbagi pengetahuan (4) mendorong inovasi dan kreativitas. (5) mempertinggi sensitivitas terhadap perubahan lingkungan.

Dalam sesi individual consideration, bertujuan agar peserta pelatihan mampu (1) mendengarkan kebutuhan masing-masing pengikut dan kekhawatiran. mengekspresikan ucapan terima kasih atau pujian sebagai sarana motivasi membuat pengakuan publik dari prestasi dan inisiatif. (3) membuat catatan pribadi ucapan selamat untuk meningkatkan rasa percaya diri (4) menjamin distribusi beban kerja yang adil, menghargai usaha individual, konseling karir dan mentoring.

Aspek-aspek tersebut disusun lebih rinci dalam modul Pelatihan Kepemimpinan Transformasional. Berdasarkan hasil pelatihan kepemimpinan transformasional bagi para supervisor, diharapkan dapat meningkatkan mutu pelayanan para pramuniaga.

Penelitian ini menggunakan desain quasi experiment, yaitu pengukuran pre test post test control group design dengan menggunakan kelompok eksperimen dan kelompok control (Cook \& Campbell, 1979).

Rancangan penelitian ini dapat digambarkan sebagai berikut: 
Tabel 1. Rancangan Penelitian

\begin{tabular}{lll}
\hline KE & O1 $\quad \mathrm{O}$ & O2 \\
KK & O2 & O2 \\
\hline Keterangan symbol: & \\
KE & : Kelompok Eksperimen \\
KK & : Kelompok Kontrol \\
$\mathrm{X}$ & : Perlakuan \\
$\mathrm{O}$ & : Pengukuran Perilaku
\end{tabular}

Penelitian mengenai pengaruh pelatihan kepemimpinan transformasional terhadap mutu pelayanan ini merupakan penelitian eksperimental. Ciri penelitian eksperimental adalah adanya manipulasi pada variabel bebas pada kelompok eksperimen (Cook \& Campbell, 1979). Manipulasi variabel bebas dalam penelitian ini berupa pelatihan kepemimpinan transformasional para supervisor bagi para pramuniaga yang mutu pelayanannya sedang sampai rendah. Melalui pelatihan kepemimpinan transformasional berisi sesi-sesi yang mengacu pada teori Bass (2003) yang berisi metode permainan, menonton film dan diskusi yang disesuaikan dengan tujuan pelatihan. Setelah pelatihan, para supervisor akan melaksanakan hal-hal yang telah dilakukannya selama pelatihan. Untuk melakukan kontrol terhadap perilaku kepemimpinan para supervisor setelah pelatihan tersebut, selama satu minggu peneliti bekerjasama dengan manajer Flora Group.

Sebagai penerapan dari pelatihan sesi individualized influence, para supervisor akan menjadi sosok panutan bagi para pramuniaganya. Misalnya dalam kedisiplinan masuk dan pulang kerja, selalu berada di area penjualan ketika toko buka, berpenampilan rapih sesuai aturan perusahaan dan memberi contoh dalam memberikan mutu pelayanan yang baik untuk kepuasan pembeli. Untuk penerapan sesi inspirational motivation, para supervisor akan berperilaku sebagai motivator dan inspirator bagi para pramuniaga, yaitu dengan memberikan semangat dan inspirasi untuk memberikan mutu pelayanan yang baik bagi para konsumen. Misalnya ketika ada pembeli yang meminta diajari cara pemakaian jilbab kreatif, maka pramuniaga dimotivasi oleh supervisornya untuk bisa melakukan hal tersebut. Dalam hal penerapan sesi intellectual stimulation, para supervisor menstimulasi kerja bawahan agar inovatif dan kreatif. Contohnya ketika ada pembeli yang akan melakukan transaksi dengan kartu kredit, maka supervisor menstimulasi para pramuniaga agar selalu dapat menggunakan mesin pelayanan kartu kredit yang tersedia. Pramuniaga distimulasi agar mau belajar menguasai teknologi yang ada untuk memberi mutu pelayanan yang baik demi kepuasan pembeli. Untuk penerapan sesi individual consideration, para supervisor memberi perhatian khusus bagi para pramuniaga untuk berprestasi dan berkembang, dengan bertindak sebagai fasilitator atau mentor. Contohnya apabila ada pembeli yang mau bertransaksi dengan kartu kredit, namun pramuniaga bagian pembayaran tidak dapat mengoperasikan mesin tersebut, supervisor tidak langsung menegur di depan pelanggan, namun bersedia mengajarkan pramuniaga untuk mengatasi masalah tersebut.

Subjek dalam penelitian ini adalah semua pramuniaga yang ada di seluruh unit bisnis Flora Group dengan ciri-ciri masa kerja minimal 1 tahun, usia 20-40 tahun dan tingkat 
pendidikan minimal SMA. Subjek yang digunakan dalam penelitian ini adalah subjek yang memiliki skor sedang sampai rendah dalam skala mutu pelayanan. Direncanakan akan dibagi menjadi dua kelompok yaitu kelompok kontrol dan kelompok eksperimen. Skala Mutu pelayanan yang digunakan terdiri dari 47 butir pernyataan untuk mengetahui mutu pelayanan yang telah dilakukan oleh pramuniaga. Penyusunan skala mutu pelayanan berdasarkan dimensi SERVQUAL yang dikemukakan oleh Parasuraman, Zeithaml \& Berry (1998).

Penelitian diawali dengan melibatkan seluruh pramuniaga untuk mengisi skala mutu pelayanan. Berdasarkan skor skala itu, maka dipilih yang rendah sampai sedang. Pramuniaga yang memiliki skor rendah sampai sedang tersebut dibagi menjadi kelompok eksperimen dan kelompok control. Data yang telah diperoleh merupakan data pre test. Dua minggu setelah pelaksanaan pelatihan, kemudian dilakukan post test untuk mengetahui efektifitas pelatihan kepemimpinan transformasional para supervisor terhadap mutu pelayanan pramuniaga. Post test dilakukan dengan menggunakan skala mutu pelayanan. Metode analisis data yang digunakan adalah uji t (ttest). Metode ini merupakan prosedur pengujian parametric rata-rata dua kelompok data. Data yang dimaksudkan dalam penelitian ini adalah data dari kelompok control dan kelompok eksperimen. Penelitian dimulai 23 Juni 2015 dan berakhir pada 14 Desember 2015. Penelitian dibagi menjadi dua tahap, yaitu tahap persiapan penelitian dan tahap pelaksanaan penelitian.

\section{HASIL DAN PEMBAHASAN}

Data yang dipergunakan untuk pengujian hipotesis adalah data yang diperoleh dari pretest dan posttest mutu pelayanan. Berdasarkan hasil pengumpulan data mutu pelayanan secara empiris pada kelompok kontrol dan kelompok eksperimen. Hasil pengumpulan data pretest menunjukkan skor terendah mutu pelayanan pada Kelompok Eksperimen $=61$ dan skor tertinggi $=101$ dengan skor rata-rata (mean) $=82,12$ dan standar deviasi $=12,041$. Sedangkan pada Kelompok Kontrol skor terendah mutu pelayanan $=60$ dan skor tertinggi $=99$ dengan skor rata-rata $($ mean $)=80,80$ dan standar deviasi $=11,040$

Hasil pengumpulan data posttest setelah diberi perlakuan menunjukkan skor terendah mutu pelayanan pada Kelompok Eksperimen = 136 dan skor tertinggi $=183$ dengan skor ratarata $($ mean $)=157,53$ dan standar deviasi $=$ 16,133. Sedangkan pada Kelompok Kontrol skor terendah mutu pelayanan $=74$ dan skor tertinggi $=117$ dengan skor rata-rata $($ mean $)=$ 101,67 dan standar deviasi $=12,709$. Hasil analisis data dengan sampel t-test, skor pada skala mutu pelayanan antar kelompok dapat dilihat pada tabel 2 .

Tabel tersebut menunjukkan hasil analisis pada data pretest diperoleh $\mathrm{t}$ hitung 0,321 dengan $\mathrm{p}=0,750(\mathrm{p}>0,05)$ yang berarti tidak ada perbedaan yang signifikan mutu pelayanan sebelum pelatihan antara kelompok eksperimen dengan kelompok kontrol. Hasil 
analisis pada data post test diperoleh t hitung 10,775 dengan $\mathrm{p}=0,000$ yang berarti ada perbedaan yang signifikan antara kelompok eksperimen dengan kelompok kontrol sesudah pelatihan. Dilihat dari mean atau rata-rata skor posttest, kelompok eksperimen lebih tinggi dibanding dengan kelompok kontrol. Dengan demikian dapat dikatakan bahwa mutu pelayanan pramuniaga kelompok eksperimen sesudah adanya pelatihan kepemimpinan transformasional para supervisornya, mutu pelayanan kelompok eksperimen lebih tinggi dari pada kelompok kontrol.

Tabel 2. Skor pada Skala Mutu Pelayanan Antar Kelompok

\begin{tabular}{|c|c|c|c|c|c|c|}
\hline $\begin{array}{l}\text { Dat } \\
\text { a }\end{array}$ & $\begin{array}{l}\text { Kelo } \\
\text { mpok }\end{array}$ & $\begin{array}{l}\mathrm{Me} \\
\text { an }\end{array}$ & SD & $\mathrm{t}$ & $\mathrm{p}$ & $\begin{array}{l}\text { Ketera } \\
\text { ngan }\end{array}$ \\
\hline \multirow{6}{*}{$\begin{array}{l}\text { Pre } \\
\text { Tes } \\
t\end{array}$} & Eksp & 82. & 12. & \multirow{6}{*}{$\begin{array}{l}0.3 \\
21\end{array}$} & \multirow{6}{*}{$\begin{array}{l}0.7 \\
50\end{array}$} & \multirow{6}{*}{$\begin{array}{l}\text { Tidak } \\
\text { signifi } \\
\text { kan }\end{array}$} \\
\hline & $\begin{array}{l}\text { erime } \\
\mathrm{n}\end{array}$ & 12 & 041 & & & \\
\hline & & & & & & \\
\hline & & & & & & \\
\hline & & & & & & \\
\hline & $\begin{array}{l}\text { Kontr } \\
\text { ol }\end{array}$ & $\begin{array}{l}80 . \\
80\end{array}$ & $\begin{array}{l}11 . \\
040\end{array}$ & & & \\
\hline \multirow{7}{*}{$\begin{array}{l}\text { Pos } \\
\text { t } \\
\text { Tes } \\
t\end{array}$} & Eksp & 157 & 16. & \multirow{7}{*}{$\begin{array}{l}10 . \\
775\end{array}$} & \multirow{7}{*}{$\begin{array}{l}0.0 \\
00\end{array}$} & \multirow{7}{*}{$\begin{array}{l}\text { Signifi } \\
\text { kan }\end{array}$} \\
\hline & $\begin{array}{l}\text { erime } \\
\mathrm{n}\end{array}$ & .53 & 133 & & & \\
\hline & & & & & & \\
\hline & & & & & & \\
\hline & & & & & & \\
\hline & Kontr & 101 & 12. & & & \\
\hline & ol & .67 & 709 & & & \\
\hline
\end{tabular}

Hasil analisis uji t ukur ulang pada kelompok eksperimen menunjukkan mean pretest $=82,12$ dan mean post test $=157,53$ dengan $\mathrm{t}$ hitung 32,957, $\mathrm{p}=0,000$ menunjukkan adanya perbedaan yang signifikan mutu pelayanan pramuniaga antara sebelum dan sesudah supervisornya diberi pelatihan kepemimpinan transformasional. Artinya mutu pelayanan pramuniaga sesudah supervisornya diberi pelatihan lebih baik daripada sebelum supervisornya diberi pelatihan.

Berdasarkan hasil ananlisis data penelitian diketahui bahwa ada perbedaan mutu pelayanan antara kelompok kontrol dan kelompok eksperimen. Berdasarkan hal tersebut menunjukkan bahwa hipotesis yang diajukan dalam penelitian diterima, artinya mutu pelayanan pramuniaga yang supervisornya diberi pelatihan kepemimpinan transformasional (kelompok eksperimen) lebih tinggi daripada mutu pelayanan pramuniaga yang para supervisornya tidak diberi pelatihan kepemimpinan transformasional (kelompok kontrol). Hal ini dapat dilihat dari hasil pengujian hipotesis dengan menggunakan uji independent sampel $t$-test, menunjukkan nilai $\mathrm{t}$ sebesar $\mathrm{t}=10,775 \quad(\mathrm{p}<0,01) \quad$ yang menunjukkan adanya perbedaan yang signifikan antara kelompok control dan kelompok eksperimen.

Hasil penelitian ini membuktikan bahwa pelatihan kepemimpinan transformasional terbukti efektif dalam meningkatkan mutu pelayanan pramuniaga. Temuan ini selaras dengan pernyataan Farida (2006) bahwa pelatihan dapat memunculkan perubahan perilaku sebagai akibat dari pemahaman dan pengalaman yang diperoleh selama mengikuti pelatihan. Pelatihan kepemimpinan transformasional yang dilaksanakan juga berhasil memperbaiki pengetahuan dan skill individu, serta terbukti dapat diterapkan dalam konteks permasalahan sehari-hari para supervisor dalam meningkatkan mutu pelayanan pramuniaga. 
Pelatihan

kepemimpinan

transformasional sebagai salah satu metode atau teknik untuk meningkatkan mutu pelayanan pramuniaga sebuah perusahaan. Dasar dari pelatihan ini adalah teori Bass (2003) yang merumuskan empat ciri yang dimiliki oleh seorang pemimpin sehingga memiliki kualitas transformasional. Keempat ciri tersebut adalah idealized influence, inspirational leadership, intellectual stimulation dan individual consideration. Secara lebih rinci, dari empat aspek tersebut disusun dalaam bentuk modul pelatihan kepemimpinan transformasional. Berdasarkan hasil pelatihan kepemimpinan transformasional bagi para supervisor, diharapkan dapat meningkatkan mutu pelayanan para pramuniaga.

Aspek pertama kepemimpinan transformasional yaitu idealized influence. Pemimpin harus dapat menjelaskan tujuan dan bertindak sesuai dengan keyakinannya Dalam hal ini seorang pemimpin bertindak sebagai panutan bagi bawahannya. Aspek kedua adalah inspirational leadership. Pemimpin dalam hal ini harus bertindak sebagai pioneer, seorang pemimpin harus membantu bawahan agar dapat menemukan kesempatan, inovasi, perkembangan dan perbaikan. Aspek ketiga adalah intellectual stimulation. Pemimpin secara berkesinambungan memberikan stimulasi agar bawahan dapat bekerja dengan baik, khususnya dalam meningkatkan mutu pelayanan. Aspek keempat adalah individual consideration, dimana pemimpin mampu menghargai bawahan, menyadari kontribusi dan dapat merayakan keberhasilan. Para supervisor menghargai bawahan dalam bekerja.

Pada sesi idealized influence, peserta pelatihan diberi materi untuk (1)mengartikulasikan visi dan menjelaskan bagaimana untuk mencapai visi tersebut. (2) memimpin dengan contoh bertindak percaya diri dan optimis berbagi risiko. menekankan nilai-nilai dan memperkuat karyawan dengan tindakan simbolis perilaku etika dan moral (4) Pemimpin yang menerapkan pengaruh ideal pada pengikut mereka mendapatkan kepercayaan dan keyakinan dari para pengikut. Para pengikut mengagumi pemimpin sebagai panutan dan menghormati keputusan yang diambil.

Setelah pelatihan ini para supervisor mampu menjadi panutan dan dapat mempengaruhi pramuniaga untuk optimis mencapai target penjualan dengan memberikan mutu pelayanan terbaik. Contohnya disiplin, berpenampilan rapih, berseragam, menjaga kebersihan toko, cepat tanggap terhadap keluhan konsumen, sopan, ramah, sabar terhadap setiap konsumen. Dengan adanya sosok supervisor sebagai panutan dan memberikan pengaruh ideal dalam memberikan mutu pelayanan yang baik, maka pramuniaga akan percaya diri, optimis dan termotivasi untuk memberi mutu pelayanan yang baik pula bagi para konsumen. Supervisor yang disiplin, tepat waktu pada waktu masuk kerja, berpenampilan menarik, bersih, ramah serta bersemangat dalam melayani konsumen merupakan contoh bagi para pramuniaga dalam berperilaku bekerja dan melayani konsumen. 
Pada sesi inspirational motivation, para peserta diberi pelatihan yang bertujuan (1) mengartikulasi pandangan yang jelas dan menarik dari perkembangan masa depan visi bersama baik secara ekonomi dan ideologis sehingga karyawan mampu melihat makna dalam pekerjaan mereka. (2) memastikan peran masing-masing karyawan dalam pemenuhan visi. (3) menetapkan standar tinggi untuk para karyawan dalam mencapai tujuan. (4) mendorong karyawan untuk mengintegrasikan dan menjadi bagian dari organisasi dan lingkungan.

Setelah mendapat pelatihan dari sesi ini supervisor dapat menginspirasi pramuniaga tentang makna pekerjaan mereka. Pramuniaga tidak sekedar sebagai tenaga penjual atau pelayan saja, namun juga merasakan bahwa dirinya adalah bagian penting dari perusahaan. Hal tersebut dapat menginspirasi pramuniaga untuk melakukan mutu pelayanan yang baik.

Pramuniaga akan terinspirasi untuk memahami berbagai kebutuhan konsumen yang berbeda-beda. Misalnya konsumen ingin dibantu untuk mencari pasangan baju yang sesuai dengan warna roknya, maka pramuniaga akan dengan senang hati membantu konsumen tersebut. Ada pula konsumen yang ingin tampak langsing dengan pakaian yang akan dibelinya, maka pramuniaga dapat terinspirasi untuk menjadi advisor bagi konsumen. Hal ini dapat dirasakan pramuniaga sebagai bentuk peningkatan perannya tidak hanya sebagai pelayan toko saja.

Untuk sesi intellectual stimulation, peserta diberi pelatihan agar mampu (1) mendorong perubahan melalui stimulasi intelektual yang bertujuan untuk perubahan diri mencerminkan nilai-nilai dan keyakinan. (2) meningkatkan kesadaran dan mengembangkan kemampuan karyawan untuk memecahkan masalah. (3) menciptakan lingkungan yang kondusif bagi penciptaan dan berbagi pengetahuan (4) mendorong inovasi dan kreativitas. (5) mempertinggi sensitivitas terhadap perubahan lingkungan.

Dalam hal ini, setelah pelatihan supervisor mampu memotivasi para pramuniaga dalam memecahkan masalah. Misalnya memotivasi pramuniaga agar dapat melayani konsumen yang menginginkan pembayaran dengan menggunakan kartu kredit. Pramuniaga harus mau mempelajari proses pembayarannya jika memang sudah tersedia fasilitas mesin untuk pembayaran dengan menggunakan kartu kredit. Hal ini merupakan bagian dari peningkatan kesadaran bagi pramuniaga agar dapat meningkatkan kemampuan pramuniaga dalam memecahkan masalah dan lebih sensitive terhadap perubahan lingkungan bisnis saat ini.

Contoh lain misalnya ada konsumen yang minta diajari gaya menggunakan jilbab kreatif. Pramuniaga akan selalu bersedia mengembangkan kemampuan intelektualnya dan menjadi lebih percaya diri jika supervisor menstimulasi munculnya perilaku tersebut. Artinya supervisor memiliki kemauan untuk mendorong pramuniaga agar lebih inovatif dan kreatif dalam melayani konsumen.

Dalam sesi individual consideration, bertujuan agar peserta pelatihan mampu (1) mendengarkan kebutuhan masing-masing 
pengikut dan kekhawatiran.

mengekspresikan ucapan terima kasih atau pujian sebagai sarana motivasi membuat pengakuan publik dari prestasi dan inisiatif. (3) membuat catatan pribadi ucapan selamat untuk meningkatkan rasa percaya diri (4) menjamin distribusi beban kerja yang adil, menghargai usaha individual, konseling karir dan mentoring.

Setelah mendapatkan pelatihan dari sesi ini, supervisor memiliki kemampuan memahami dan menghargai pramuniaga secara individu. Misalnya pramuniaga dapat melakukan penjualan atau mengatasi keluhan dan masalah konsumen, maka supervisor akan memberikan pujian pada pramuniaga tersebut. Supervisor dapat membuat catatan keberhasilan itu dan berbagi dalam forum bersama pramuniaga lainnya, sebagai bahan pembelajaran dan pengakuan terhadap prestasi pramuniaga.

Demikian pula jika pramuniaga mengalami kesulitan, maka supervisor selalu siap membantunya dengan baik. Pramuniaga akan semakin bersemangat dalam memberikan pelayanan yang bermutu untuk para konsumen. Kriteria Mutu Pelayanan dalam penelitian ini berdasarkan teori Parasuraman, Zeithaml dan Berry (1988) yang menyatakan lima dimensi layanan bermutu yaitu :

a. tampilan fisik, yaitu kemampuan untuk memberikan pelayanan dengan adanya fasilitas fisik, perlengkapan dan personel

b. reliabilitas, yaitu kemampuan untuk memberikan pelayanan yang dapat diandalkan dan akurat

c. responsif, yaitu keinginan untuk membantu ,konsumen dan memberikan pelayanan dengan sebaik mungkin

d. keyakinan, yaitu pengetahuan dan kebaikan karyawan untuk memberikan kepercayaan dan keyakinan

e. empati, kepedulian dan perhatian karyawan terhadap pelanggannya secara individu.

Menurut Spiro dan Weitz (dalam Haryanti, 1999) salah satu faktor yang mempengaruhi mutu pelayanan pramuniaga adalah gaya kepemimpinan yang dipergunakan oleh supervisornya. Seorang supervisor yang memberikan arahan kepada para pramuniaga untuk mengembangkan berbagai macam pendekatan dalam pelayanan, akan memotivasi pramuniaga untuk memodifikasi pelayanan yang diberikan pada konsumen sesuai dengan situasi yang ada.

Hasil penelitian ini secara akurat mampu membuktikan bahwa pelatihan kepemimpinan transformasional supervisor mampu meningkatkan mutu pelayanan pramuniaga. Hal ini sesuai dengan teori experiential learning yang menyatakan bahwa metode pelatihan merupakan metode yang efektif untuk menambahkan atau meningkatkan keahlian dan ketrampilan peserta pelatihan dalam domain yang spesifik. Ditinjau dari perbandingan rerata pada saat pretest, terdapat perbedaan rerata yang cukup jauh. Manfaat pelatihan kepemimpinan transformasional ini terpantau jelas ketika tahap postest di mana kelompok eksperimen mampu memunculkan gap atau kesenjangan mutu pelayanan dengan kelompok kontrol. 
Sebagai penguat hasil eksperimen, peneliti juga melakukan wawancara pasca penelitian dengan dua orang manajer, untuk mengetahui ada tidaknya manfaat pelatihan kepemimpinan transformasional dari sudut pandang pihak manajerial. Hal ini dilakukan mengingat penelitian ini telah berlangsung cukup lama. Hasil wawancara dengan manajer SDM didapati bahwa setelah mengikuti pelatihan, para supervisor menunjukkan semangat lebih besar untuk menjadi panutan bagi pramuniaga, menginspirasi, memotivasi dan memperhatikan kelemahan dan kelebihan pramuniaga dalam memberikan pelayanan kepada para pelanggan.

Berbeda halnya dengan manajer operasional yang menilai manfaat pelatihan kepemimpinan transformasional memberikan kontribusi signifikan pada peningkatan mutu pelayanan pramuniaga sehingga mencapai target penjualan. Manajer operasional meyakini bahwa pelatihan kepemimpinan transformasional akan lebih bermanfaat pada upaya para supervisor sebagai contoh bagi para pramuniaga, menginspirasi, memotivasi dan lebih memperhatikan pramuniaga dalam memberikan pelayanan yang bermutu. Berdasarkan hasil wawancara dengan dua manajer, dapat disimpulkan bahwa pelatihan kepemimpinan transformasional dapat memberikan manfaat bagi peningkatan mutu pelayanan pramuniaga.

Penelitian ini juga memiliki beberapa kelemahan. Pertama yakni kelemahan self report berupa skala mutu pelayanan. Pramuniaga memiliki kecenderungan untuk melaporkan mutu pelayanan yang baik akibat dari pengaruh bias keinginan sosial. Idealnya teknik pengumpulan data menggunakan self report juga dilengkapi dengan alat ukur yang mengacu pada pendapat pelanggan atau konsumen, hasil dua arah ini lebih dapat menciptakan hasil yang akurat. Kelemahan kedua adalah adanya pengaruh internal yang tidak dianalisa misal tipe kepribadian, jenis kelamin, pengalaman dan kondisi psikologis yang dapat berpengaruh pada mutu pelayanan pramuniaga. Faktor-faktor internal tersebut tentunya dapat turut mempengaruhi peningkatan mutu pelayanan pada pramuniaga, namun tidak ditempatkan secara khusus sebagai variabel.

\section{KESIMPULAN}

Berdasarkan hasil dan pembahasan penelitian, diketahui bahwa terdapat perbedaan yang signifikan mutu pelayanan pramuniaga yang supervisornya diberi pelatihan kepemimpinan transformasional dan yang tidak diberi pelatihan. Pramuniaga yang supervisornya diberi pelatihan kepemimpinan transformasional mengalami peningkatan mutu pelayanan.

Pelatihan kepemimpinan transformasional terbukti dapat meningkatkan mutu pelayanan pramuniaga. Selanjutnya disarankan kepada pimpinan atau manajer perusahaan untuk menggunakan pelatihan kepemimpinan transformasional sebagai salah satu metode meningkatkan mutu pelayananan pramuniaga, yang pada akhirnya dapat mendukung terciptanya kepuasan pelanggan. Pelatihan kepemimpinan tranformasional perlu dirancang dan dikaji secara mendalam oleh 
perusahaan, sesuai dengan karakteristik pekerjaan maupun visi dan misi dari organisasi, sehingga hasil yang diperoleh sesuai dengan yang diharapkan.

Bagi peneliti selanjutnya, pertama, disarankan perlunya alat ukur mutu pelayanan yang berbasis pencapaian ataupun penilaian pihak lain, baik dari pihak pimpinan maupun dari pelanggan. Pengambilan data berbasiskan penilaian pelanggan dapat merepresentasikan hasil yang lebih akurat, mengingat pelayanan itu sendiri berfokuskan pada kebutuhan dan kepentingan pelanggan. Perlu dipertimbangkan pula mekanisme penilaian yang mengacu pada standar mutu pelayanan yang ditetapkan perusahaan sesuai dengan jabatan dan spesifikasi pekerjaan masingmasing individu. Kedua, pentingnya mengkaji atau mengendalikan faktor-faktor lain, baik internal maupun eksternal yang dinilai dapat mempengaruhi perubahan nilai pretest menuju posstest mutu pelayanan, termasuk halnya kondisi faktual individu bersangkutan dan situasi lingkungan kerja di dalam perusahaan.

\section{DAFTAR PUSTAKA}

Adicondro, F.G. (2003). Analisis Kualitas Layanan (Studi pada Pasaraya Grande Jakarta. Tesis (tidak diterbitkan). Program Magister Manajemen Universitas Gadjah Mada Yogyakarta.

Andrew, D.P.S. (2004). The effect of congruence of leadership behaviours on motivation, commitment and satisfaction of college tennis players (Disertasi) Orlando: The Florida State University.

Aristika, P. (2001). Manajemen Sumber Daya Manusia. Yogyakarta: PustakaPelajar.
Bass, B. \&Avolio, B. (2003).Multifactor leadership questionnaire feedback report. New York: Mind Garden Inc.

Bosshoff, C \& Mels, G. (1995). A causal model to evaluate the relationship among supervisor, rate stress, organizational commitment and internal service quality. European Journal of marketing. Vol 29, no 2, 23-42.

Bass, B. (1985). Leadership and Performance Beyond Expectation. New York: Free Press.

Bass, B. \&Avolio, B. (2003).Multifactor leadership questionnaire feedback report. New York: Mind Garden Inc.

Burn, J. \& Bass, B. (1990). Transformasional dan Transaksional Leadership. New York: Mc Graw Hills.

Clothier (1994). Tenaga penjualan dalam perusahaan retail. Bandung: Rossda Karya.

Cook, T.D. \& Campbell, D.T. 1979. QuasiExperimentation: Designs \& Analysis Issues for Field Settings. USA: Houghton Mifflin Company.

Eyal, O \& Roth, G. (2010). Principals 'leadership and teachers' motivation : Self determination theory analysis. Journal of Educational Administration, 49 (3), 256-275.

Fitri,W.(1999). Pengaruh Pelayanan Pramuniaga terhadap Sikap dan Persepsi Konsumen. Tesis. (tidak diterbitkan) . Fakultas Ekonomi Universitas Indonesia.

Gretchen dan Mishra. (2002). To Stay or To Go: Customer Service. Journal of Organizational Behavior 23,707 - 729.

Gumilar, R. (2012). Pengaruh pelatihan kepemimpinan transformasional dan motivasi terhadap kinerja karyawan dalam upaya meningkatkan kualitas pelayanan administrasi akademik di Sekolah Tinggi Ilmu Ekonomi se Kota Bandung. Tesis. (tidak diterbitkan). 
Fakultas Ekonomi Universitas Padjajaran

Hassan,M., Sharoon, S., \& Arnold, S (2010). Pre training motivation and the effectiveness of transformational leadership training: an experiment. Journal of academy of strategic management, 9 (2), 123-131.

Haryanti, K. (1999). Hubungan Persepsi Mutu Pelayanan dan Nilai Konsumen dengan kepuasan konsumen. Tesis . (tidak diterbitkan). Fakultas Psikologi Universitas Gadjah Mada.

Herscovitch, L., \& Mayer, J. P. (2002). Commitment to Customer Servive. Journal of Applied Psychology Vol. 87 ,474 - 487.

Hou, W. (1997). Practical marketing. Pemasaran Praktis Cara Asia. Jakarta: Mega Media.

Humaira, L. (2012). Pelatihan kepemimpinan transformasional untuk meningkatkan persepsi perilaku kepemimpinan atasan dan motivasi kerja bawahan. (Studi pada karyawan Cabang Y PT. X) Tesis. (tidak diterbitkan). Fakultas Psikologi Universitas Indonesia

Jabnoun, N dan Al Rasasi A.J. (2005). Transformational Leadership and service quality in UAE Hospitals. An Internanational journal, Vol. 15, 70-81.

Jefri \& Wijaya, P. (2008). Pengaruh Kualitas Layanan terhadap kepuasan, kepercayaan dan komitmen. Jurnal Riset Manajemen dan Bisnis, 3 (1), 2137.

Jewell. (1998). Contemporary Industrial / Organizational Psychology 3rd Edition. USA:Internalional Thomshon Publishing.

Johannes . (1986). Perkembangan Industri di Indonesia.Jakarta: Gramedia

Kerlinger, F. N. (2004). Asas-Asas Pelayanan Retail. Yogyakarta: Gadjah MadaUniversity press.
Kolb, D. A. (1984). Experiental Learning : Experience as the Source of Learning and Development. Englewood Cliffs. NJ: Prentice Hall

Kotler, P\& Armstrong, G.(2008). Prinsipprinsip Pemasaran, edisi 12. Penerbit Erlangga : Jakarta

Masi, R.J \& Cooke, RA. (2000). Effects of transformational leadership on subordinate motivation, empowering norms and organizational productivity. International Journal of Organizational Analysis, 8 (1), 16-47.

Miner, J. B. (1992). Industrial Organizational Psychology. New york: Mc.Graw Hill, Inc.

Parasuraman A., Zeithaml, V. dan Berry, L. (1988). SERVQUAL: A Multiple-Item Scale for Measuring Consumer Perceptions of Service Quality. Journal of Marketing Vol. 80.

Peter, K.C. lee, T.C Edwin \& Kee Hung lai.(2011). An empirical study of transformational leadership, team performance and service quality in retail banks, Journal omega Vol. 39 no 6.

Pranowo. S. (2003). Analisis Kualitas Pelayanan Sub Dinas Catatan Sipil Wonogiri. Tesis (tidak diterbitkan). Magister Administrasi Publik. Universitas Gadjah Mada Yogyakarta.

Purwanto, B. \& Adisubroto, D. (2000). Hubungan antara gaya kepemimpinan transformasional dan transaksional dengan komitmen terhadap organisasi. Sosiohumanika. 14 (1), 245-263.

Rahmad, (2013). Pengaruh komitmen organisasi dan kemampuan SDM terhadap efektifitas pelayanan di rs khusus janntung cabang utama sumbar. Jurnal ekonomi STIE Agus Salim Bukit Tinggi, Vol. 14 no. 2

Revida, E \& Batubara A.H. (2009). Pengaruh komitmen birokrasi dan total quality management terhadap mutu pelayanan 
ijin usaha industry. Jurnal kinerja vol. 13, nomor 2, 185-194.

Riggio, R.E. (2009). Introduction to Industrial/organizational Psychology. NJ: Pearson Education, Inc.

Riyono, B. \& Zulaifah, E. (2001). Psikologi Kepemimpinan. Yogyakarta: Unit Publikasi Fakultas Psikologi UGM.

Steers, R. \& Porter (1991). Motivation and work behavior. New York: Mc Graw Hill.

Suharta,Y.(2014).Hubungan antara persepsi gaya kepemimpinan transformasional dan komitmen organisasi dengan mutu pelayanan kesehatan pada perawat di rumah sakit umum daerah Panembahan Senopati Bantul.

Usmara, A. \& Nugroho, E.P. (2000).
Pengujian Kualitas Jasa, Kepuasan Nasabah dan Intensi Pembelian Ulang. Sosiohumanika, 13 (1), 215-228.

Wignyowiyoto, S. (2002). Leadershipfollowership. Hubungan Dinamis kepemimpinan-keanakbuahan sebagai kunci sukses organisasi. Jakarta: Penerbit PPM.

Yudhawati, D. (2005). Hubungan persepsi gaya kepemimpinan transformasional, transaksional dan komitmen organisasional dengan mutu pelayanan pramuniaga Matahari Department Store Magelang. Tesis. (tidak diterbitkan). Fakultas Psikologi Universitas Gadjah Mada.

Yukl, G. (1998). Kepemimpinan Dalam Organisasi. Edisi Indonesia. Jakarta: Penerbit PT Indeks. 